\title{
NÓGRÁDI-SZABÓ ZOLTÁN
}

\section{HISZEM, AMIT LÁTOK, VAGY LÁTOM, AMIT HISZEK? ETNOGRÁFIA A KVALITATÍV PIACKUTATÁSBAN A TEREPMUNKÁTÓL A VIDEOFILMIG}

A cikk az akadémiai kvalitatív kutatásokban és a kvalitatív piackutatásban alkalmazott etnográfiai kutatások sajátosságait hasonlítja össze. Foglalkozik a mindkettő megközelítést illető kritikákkal, az objektivitás és a szubjektivitás kérdésével. A szerző kitér a kulturális antropológia piacorientált etnográfiai kutatásokra gyakorolt hatásaira, a hasonlóságokra és a különbségekre. Az etnográfiai kutatások sajátossága, hogy a kutatások eredményeit nem csak írott anyagok, tanulmányok rögzítik, hanem videofelvétel is. A cikk bemutatja a videorögzítés különböző fajtáit és az egyes típusok közötti különbségeket. A kvalitatív piackutatásban használt etnográfia lefedi az élet legfontosabb dimenzióit, beleértve a fizikai és szociális környezetet, kulturális kontextust és a személyiséget. A szerző bemutatja a piackutatás során használt különböző etnográfiai technikákat, az etnográfiai kutatás tervezését, a tartalmi blokkok és a passzív/aktív részek szerepét, valamint időbeli különválasztását. Végezetül a cikk foglalkozik a kvalitatív piackutatásban alkalmazott etnográfia jövőjével, az online technológiák lehetőségeivel az offline viselkedések megfigyelésében és rögzítésében.

Kulcsszavak: etnográfia, kvalitatív kutatás, piackutatás, kulturális antropológia, videofilm

$\mathrm{Az}$ akadémiai kvalitatív kutatási technikák és a piackutatásban alkalmazott kvalitatív kutatások között jelentős különbségek lehetnek. Az üzleti piackutatásban használt etnográfia projektalapú, spontán szemlélődő jellegét megtartotta, de a kutató képzeletbeli kamerája - a kutatási projekt fókuszpontjai alapján - szürőket kapott. Az etnográfiai kutatás a piackutatásban egy megfigyelésen alapuló módszertan, amit interjúk egészítenek ki. Magában foglalja a kulturális mező valamennyi elemét, lefedi az élet legfontosabb dimenzióit. Az akadémiai kutatásokban az etnográfia egy rugalmas módszer, ami számos szituációhoz könnyen alakítható, leíráscentrikus és a sok esetben a közösségek életét vizsgálja. A kvalitatív piackutatásban használt etnográfia egy módszertani tárház, egyfajta „svédasztal”, amiről a kutató a kutatási kérdések megválaszolásához legmegfelelőbb módszertani technikát választja ki, ami általában egy meghatározott területre koncentrál. Az üzleti világban az etnográfiai módszerek fókuszáltak, több technikai eszközt használnak. A piackutatásban használt etnográfiai kutatásoknál kihívást jelent megtartani az akadémiai etnográfiai kutatásokra jellemző naiv szemlélődést amellett, hogy a megbízó által meghatározott kutatási kérdésekre koncentrálunk, ami az üzleti hatékonyság alapvető feltétele. Az akadémiai kutatásokban használt etnográfiai megközelítések naiv megfigyelés fázisa sokkal hangsúlyosabb, mint a célorientált piackutatásban használt etnográfiai módszerek esetében, ahol a naiv, passzív fázist egy aktív, kérdezésen alapuló rész követ.

\section{Szociológiai és antropológiai gyökerek}

Az etnográfia a szociológiából, antropológiából és más társadalomkutatások területéről szivárgott be a fogyasztói kutatásokba. Legjelentősebb hatással az antropológia volt rá.

A kulturális és a fizikai antropológia a XX. század folyamán különvált. Az etnográfiai kutatás szempont- jából a kulturális antropológia irányzata a lényeges, melynek fö kutatási területe az emberi kultúra (Letenyei, 2012).

Az etnográfia mint módszertan többször ment keresztül öndefiníciós problémákon, válságokon, de népszerüsége töretlen maradt (Dörnyei - Mitev, 2010). Ennek oka az etnográfiai módszertan rugalmassága, amit a felhasznált technikák segítségével mindig az éppen aktuális kutatási témához vagy kérdésekhez lehet igazítani (Kozinets, 2002).

Etnográfián sokan a szó eredeti jelentését, a néprajzot értik. Az etnográfiai kutatások terepmunkájának helyszíne az elmúlt századokban távoli, egzotikus országok voltak. Ma a kutatók a saját társadalmukat kutatják, egyfajta naiv, rácsodálkozó attitüddel viseltetve a mindennapi rutinaktivitások és jelenségek iránt. Ez egyfajta auto-antropológia, mivel a kutatók olyan társadalmi csoportokat kutatnak, melyek horizontja a sajátjukkal egybeesik (Nagy, 2006). Nagy Károly Zsolt szerint az etnográfia a társadalomtudományi terepmunka meghatározott formája. „Olyan empirikus kutatási módszer, melynek középpontjában a reflektált hermetikai pozícióban való jelenlét a résztvevés és megfigyelés (résztvevő-megfigyelés), illetve az interpretív attitűd áll” (Nagy, 2006, 1. old.).

Az etnográfia azonban nem csupán az adatgyüjtés egyik formája. Fókuszában az adott kultúrában élő emberek kapcsolatrendszere, viselkedése, élményei állnak, melynek nemcsak a kognitív szinten történö értelmezése történik, hanem az emocionális szinten való megjelenítése is.

A lényeg a természetes környezetben történő szisztematikus adatgyüjtésen és a viselkedés megfigyelésén van. A módszer elengedhetetlen jellemzője a hosszútávúság (Arnould - Wallendorf, 1994). Az etnográfus a megfigyeltek számára mindennapi eseményeket, történéseket, beszélgetéseket, interakciókat, tárgyak használatát rögzíti (Jorgensen, 1989). 
A megfigyelés típusai között megkülönböztetünk résztvevő- és nem-résztvevő megfigyelést. A résztvevő-megfigyelés során a megfigyelö maga is részese a megfigyelt eseményeknek, még a nem-résztvevő megfigyelés alkalmával a kutató megfigyeli és rögzíti a látott természetes viselkedést, de nem lesz részese az éppen folyó eseményeknek. A mechanikus megfigyelés a látottak rögzítését jelenti, sok esetben ilyenkor csak egy hang vagy képfelvevő van jelen, a kutató később elemzi és értelmezi a rögzített felvételeket (Arnould - Wallendorf, 1994).

Az etnográfiai kutatásokra jellemző módszer még a „Speech in action” technika, amikor a kutató arra kéri a megfigyelt alanyt, hogy hangosan gondolkodjon, vagy mondja el, amit éppen csinál (Richard, 1939).

A szociológiai és az antropológiai gyökerek az akadémiai etnográfiai kutatások szemléletmódjában és az alkalmazott technikáiban is tetten érhetők.

\section{Etnográfia az akadémiai kutatásokban}

\section{Mennyire tekinthető tudományos módszertannak az etnográfia?}

A kvalitatív, interpretatív vagy posztmodern kutatások minősége és tudományossága több évtizede releváns téma (Dörnyei - Mitev, 2011). Mivel az etnográfia a kvalitatív kutatások családjába tartozik, a kvalitatív kutatásokat érö kritika - miszerint nem számszerüsíthető, nem reprezentatív, nem megismételhető, nem objektív - ezt a módszert is érintette. Ezeket a kritikai hangokat külön felerösítette, hogy az etnográfiai kutatás - a kognitív mérhető vagy rögzíthető adatok mellett - emocionális jellemzőket is felhasznál, elemez.

Az objektivitás kérdése nagymértékben az érzelmi leválásban gyökerezik hiszen - Lerum szerint - csak az nevezhető tudományosnak, ahol a kutatónak nincs érzelmi elköteleződése a kutatás tárgyával szemben (Lerum, 2001).

Az etnográfiai módszerek lényeges része a látottak vizuális dokumentálása. A rögzített video- és hanganyagok tudományos szempontból sosem lesznek egyenértéküek az írott szövegek elemzésével, mivel egy videoanyag nem tudja úgy bemutatni az irodalmakat vagy a kutatás elméleti hátterét, mint egy írásos dokumentum (Kozinets - Belk, 2005).

A videofilm óriási előnye, hogy - egy tanulmánnyal ellentétben - nemcsak a kognitív tudás befogadását teszi lehetővé, hanem a rögzített élmények megosztásával emocionális szinten is képes hatni (Sherry - Schouten, 2002). Ez akkor is az etnográfia elönyének nevezhetö, ha az emocionalitás értelmezése megkérdőjelezi az etnográfiai kutatások tudományos hitelességét.

Lehet-e - és ha igen, hogyan - tudományos egy vizuális megfigyelésre alapozó módszertan? Joy szerint amíg az akadémiai hitelesség önmagában a narratívák virtuóz használatával elérhető, addig az etnográfiában a hitelességet a megfigyelt viselkedés sokoldalú értelmezése biztosítja (Joy, 1991).

\section{Az akadémiai etnográfiai kutatások jellemzői}

Akadémiainak nevezem azokat az etnográfiai kutatásokat, melyeket nem piackutatási céllal végeztek, nem elsődlegesen piacorientált céllal készültek, gyártó vagy forgalmazó cégek megbízásából. Az akadémiai etnográfiai kutatások valamilyen néprajzi, szociológiai, társadalomtudományi vagy pszichológiai kérdéssel foglalkoznak, sokszor nincs egy meghatározott, leszükített kutatási céljuk, megfigyelési és értelmezési spektrumuk széles.

A kutatók az eredményeket általában tudományos folyóiratokban vagy könyvekben publikálják. Az akadémiai etnográfiai kutatások sokszor éveken keresztül tartanak, a kutatásnak ritkán van egy megadott határideje, amikor azt be kell fejezni. A gyakorlati alkalmazás, az eredmények üzleti felhasználhatósága az akadémiai etnográfiai kutatásokban csupán az egyik dimenzió, a piacorientált etnográfiai kutatásokban viszont ez a leglényegesebb fókuszpont.

A tudományos etnográfia módszertana szorosan kapcsolódik a grounded theory kutatási módszerhez. A grounded theory olyan kutatási módszer, ahol az elmélet az empirikus adatokból fejlődik ki és abban gyökerezik (Glaser - Strauss, 1967).

A tudományos céllal készített etnográfiai kutatások másik gyökere a dokumentumfilm készítéséhez nyúlik vissza. Az etnográfiai filmek a dokumentumfilmek speciális formájának is felfoghatók. A dokumentumfilmmel szemben azonban az etnográfiai film tudományos jegyekkel is rendelkezik (Mitev - Dörnyei, 2011).

Az akadémiai etnográfiai megközelítésekhez tartozik az interaktív etnográfia is. Nagy Károly Zsolt szerint „az interaktív etnográfia egy olyan társadalomtudományi módszer, mely (a) az interaktivitás fogalmát használja az etnográfiai megismerési folyamat leírására, illetve szervezésére, és ezzel szoros összefüggésben (b) a kutatás tervezésétől a publikációig - illetve tovább - tudatosan, tudományos eszközként alkalmazza az interaktív hipermediális technikákat” (Nagy, 2016., 3. old.).

Pink (2007) megközelítése szerint az etnográfia az adatok összegyűjtésének módszere helyett a tudás létrehozásának és kifejezésének folyamata, amely az etnográfus saját tapasztalataira épül. Az etnográfia nem csupán az adatok összegyüjtését jelenti, hanem egyfajta tudás létrehozását, amit alapvetően befolyásol a kutatást végző etnográfus saját tapasztalata. A kutató saját tapasztalatára való támaszkodás az elemzési folyamat alatt az akadémiai etnográfiai kutatások jellemzője. A piackutatásban használt etnográfiában a kutató igyekszik kizárni a saját tapasztalatait mind a megfigyelés, mind az értelmezés fázisában.

\section{A kvalitatív piackutatásban használt etnográfia}

\section{A kulturális antropológia hatása a piacorientált etnográfiai kutatásokra - hasonlóságok és különbségek}

Az akadémiai etnográfia alapvetően a kulturális antropológia módszertani gyökereivel rendelkezik. A következőkben a kulturális antropológia történeti fejlődéséből eme- 
lem ki az általam legfontosabbnak tartott fejezeteket, és hasonlítom össze a piacorientált etnográfiai kutatásokkal.

A különbségek föleg a korai antropológiai megközelítések esetében jellemzők. A kulturális antropológia első irányzata az evolucionista antropológia, melynek képviselöje Herbert Spencer. Szerinte az emberi társadalmakra folyamatos fejlődés jellemző, és a fejlődés mögötti hajtóerők ugyanazok, mint a természetben (Letenyei, 2012). A XIX. századbeli tudósok körében elterjedt volt az a nézet, hogy a fejlődés egy piramishoz hasonlítható, a fejlödés iránya pedig lineáris. Ez az evolucionista felfogás a piackutatásban használt etnográfiára nem jellemző.

Különbséget találunk a terepmunka fókuszában is. Terepmunkát - a helyszínen való adatgyüjtést - a kulturális antropológia alkalmazta először az 1920-as években. Terepmunka alatt egy adott közösségen belül gyüjtött információkat értjük, ahol a legfontosabb elem a személyes találkozás. A piackutatásban alkalmazott etnográfiában nem a személyes találkozást helyezzük a fókuszba - hiszen az a stúdiótechnikák esetén is jelen van -, hanem a helyszínt, a válaszadó környezetét és a saját környezetben való viselkedést, valamint e viselkedés értelmezését.

Nem jellemző a piackutatásban alkalmazott etnográfiai adatgyüjtésre az etnocentrizmus sem. A piackutatásban a különböző megfigyelt szokásokat és viselkedéseket, nem a saját fogyasztói szokásainkból kiindulva, a mi értékrendünkhöz viszonyítva értelmezzük.

A Margaret Mead-féle nyíltságot a nyíltságért elv miszerint annyi információt tudunk kapni az interjúalanyoktól, mint amennyit mi is megosztunk velük - teljesen hiányzik a piackutatásban használt etnográfiából. Az etnográfiai módszertanokat alkalmazó piackutató semmit nem árul el saját értékrendjéről, fogyasztási szokásairól és nem ad visszajelzést a megfigyelés alanyainak.

A néprajzkutatás hatásait vizsgálva meg kell említenünk a nyugat-európai és a közép-európai néprajzkutatás közötti különbségeket. A néprajzkutatás Nyugat-Európában a gyarmatosítással függött össze, Közép-Európában inkább az autentikus elemek megtalálása volt a cél (Letenyei, 2012). Ez utóbbihoz jobban hasonlít a piackutatásban alkalmazott etnográfia. Különbség azonban, hogy a néprajzkutatás fel akarja tárni a múltbéli, ősi, kulturális jegyeket, a piackutatásban alkalmazott etnográfia inkább a jelenkori viselkedésre és szokásokra koncentrál.

Hasonlóságként meg kell említenünk a strukturális és a biopszichológiai funkcionalizmus közötti vitát, ami nem más, mint a módszertani holizmus és individualizmus közötti vita. A módszertani individualizmus az egyénekre, a holizmus pedig emberek egyes csoportjaira irányuló kutatási stratégiát jelenti. „A struktúrák nem vizsgálhatók önmagukban - semmi sem vizsgálható a kontextusból kiragadva" - fogalmaz Radcliffe-Brown funkcionalista megközelítésben írt cikkében (in: Letenyei, 2012, 145. old.).

A kulturális antropológia szemlélete holisztikus, tehát a kultúra anyagi és szellemi aspektusai összefüggésben állnak egymással és csak együtt értelmezhetők. A piackutatásban a holisztikus szemlélet azt jelenti, hogy a fogyasztót és a fogyasztási szokásokat a fogyasztó környezetével egységben vizsgáljuk.
A történeti partikularizmus kifejezés arra a kutatás-módszertani és etikai felfogásra utal, hogy „,minden egyes népcsoport kultúráját csak a saját természeti és környezeti adottságainak megfelelően szabad értelmezni” (Letenyei, 2012, 109. old.). Ezért az etnográfiai kutatás során kapott eredmények kevésbé általánosíthatók. Ez a szemlélet a piackutatásban használt etnográfiára is igaz.

Meg kell még említeni a kognitív antropológiát, amely gyakran használt kvalitatív tartalomelemzést, és a szimbolikus antropológiát, melynek lényege a kultúra szimbólumokban való megragadása. Mindkettő jellemző a piackutatásban használt etnográfiára is.

Végső soron Clifford Geertz által képviselt interpretatív antropológia filozófiája és módszertana áll legközelebb a piackutatásban jelenleg alkalmazott etnográfiai kutatásokhoz. Ennek két fontos pillére a megfigyelt jelenségek pontos tolmácsolása - hogy az eredeti jelentéstartalmak ne sérüljenek - és az értelmezés során az attitüd cselekvési komponensének hangsúlyozása. Geertz szavaival megfogalmazva „ha meg akarunk érteni egy tudományt, először nem az elméleteit vagy eredményeit kell megtekintenünk, és egészen biztosan nem azt, amit hívei mondanak róla - azt kell megnéznünk, hogy mit csinálnak azok, akik a gyakorlatban müvelik" (Letenyei, 2012, 176. old.).

Az antropológia posztmodern kritikája nagy hatással volt a piackutatásban használt etnográfiára. A posztmodern tagadja, hogy a világ objektíve megismerhető. Kiemeli, hogy ne akarjunk empatikusak lenni, a másik ember bőrébe bújni. Ez a szemlélet a hermeneutikai fordulathoz vezetett - az antropológusok elutasították, hogy a világ objektíve megfigyelhetö. Ezzel szemben a piackutatásban használt technikai eszközök - mint a fényképezö vagy a kamera - mind objektív, kézzel fogható kiindulópontot adnak az eredmények szubjektív értelmezésének.

\section{A piacorientált etnográfia jellemzői}

A piackutatásban használt etnográfiát piacorientált etnográfiának is hívják. A piacorientált etnográfia a viselkedést kutató tanácsadási folyamat, mely termékekkel vagy szolgáltatásokkal kapcsolatos (Arnould - Wallendorf, 1994). Ezek a kvalitatív piackutatásban használt etnográfiai kutatások, melyeket érdemes megkülönböztetni a vállalati marketingfolyamatok megismerésének érdekében használt etnográfiától, ami embereket tanulmányoz egy szervezetben, ahogy éppen marketingmanagementtel kapcsolatos tevékenységeket végeznek, mint például marketingtervezés, stratégiakialakítás, termék- vagy márkafejlesztés. A piackutatásban használt etnográfiai kutatások abban is különböznek a tudományos etnográfiai kutatásoktól, hogy a piacorientált etnográfia interpretatív jellege mellett fontos szerepet játszanak a marketingstratégia létrehozásában is, tehát eredményei széles körben felhasználtak és konkrét döntési folyamatokhoz kapcsolódnak (Arnould - Wallendorf, 1994).

Az üzleti kutatásokban egyre inkább igény mutatkozik arra, hogy azt kutassuk, amit megtapasztalunk, és a fogyasztói viselkedés, valamint a valós választások adják meg a kutatások alapját, ne pedig a válaszadók utólagos 
beszámolói. Az alkalmazott piackutatási módszertanok és technikák közül egyre gyakrabban kerültek előtérbe azok, melyek nem a fogyasztók utólagos felidézésére hagyatkoztak stúdiókörülmények között, hanem a válaszadó valós környezetében történő aktivitásokat kívánták rögzíteni.

Az etnográfiai kutatás a kvalitatív piackutatásban egy megfigyelésen alapuló módszertan, amit interjúk egészítenek ki. A terepmunka helyszíne a történés valósága, az itt és most, ahol az interakciók és az aktivitások történnek. A stúdiótechnikákkal - mint a klasszikus mélyinterjúk vagy a fókuszcsoportok - összehasonlítva a válaszadó természetes környezetében történő terepmunka sokkal mélyebb értelmezésre ad lehetőséget. A stúdiótechnikák általában felidézésre, az interjúalany emlékezetére támaszkodnak, ezek az információk gyakran - néha szándékosan, néha nem szándékosan - torzulhatnak. Ezzel szemben a fogyasztó valóságában megfigyelt és rögzített aktivitások részletes képet adnak a fogyasztó magatartásáról, nemcsak az az információ jut el a kutatóhoz, amit a fogyasztó fontosnak tart elmondani, hanem a teljes valóság. Az etnográfiai kutatás terepmunkája legalább 4-5 óra, ennyi az az idő, amit a kutató a megfigyeltekkel együtt tölt. Mivel az alanyok ilyen hosszú idő alatt nem tudják megjátszani magukat, vagy tudatosan elfedni a valóságot, a látott és a hallott információ igazságtartalma sokkal nagyobb, mint bármelyik felidézésre alapuló stúdiótechnikáé. Ez nagymértékben csökkentette a válaszadó és a kutató szubjektív torzításának lehetőségét, valós viselkedések, valós történések rögzítésével és azonnali értelmezésével gazdagította a kutatási eredményeket és növelte a kvalitatív kutatási anyagok hitelességét.

Az akadémiai etnográfiai kutatásokban ritkán alkalmazott, viszont a piackutatásban szinte mindig használt elöszelekciós technika a kvótaspecifikus szürés. Eszerint a piackutatás során a kutató nem egy bizonyos csoportot keres fel, hanem nagyon szigorú szürési kritériumok alapján kiválogatott, célcsoportba tartozó válaszadókat figyel és kérdez meg. A célcsoport leszúkítése a kutatási kérdések hatékonyabb megválaszolása érdekében történik, mely minden esetben az előre meghatározott kutatási és marketingcélokat szolgálja.

Az etnográfia tudományos módszertana az üzleti világba kerülve projektalapúvá vált, az előre meghatározott kutatási célok és kérdések megválaszolása miatt formai és időbeli korlátokat kapott. Spontán szemlélő jellegét megtartotta, de a kutató képzeletbeli kamerája egyfajta szürőket használ. Az egészleges megfigyelés mellett fókuszpontok is szerepet kaptak a szemlélödésben, melyek a kutató képzeletbeli és valós kameráját vezetik. Ezeket a szürőket a legtöbb esetben a megrendelő kutatási kérdései és a kutatás céljai állítják be vagy finomhangolják.

Kozinets és Belk (2005) leírása alapján a fogyasztói kutatásban használt videográfiának a következő fajtái lehetnek: kamerával felvett interjúk, megfigyelöi videográfia, autovideográfia, kollaboratív, retrospektív és impresszionista videográfia. A piackutatásban leggyakrabban használt etnográfiai kutatás leginkább a kamerával felvett interjúkhoz és a megfigyelői videográfiához hason- lít, de nem azonos velük. A kamerával felvett interjútól leginkább abban különbözik, hogy az etnográfiai interjú nem stúdióban, hanem a fogyasztó életterében készül, és nem a kérdezésen alapuló interjún, hanem a megfigyelésen van a hangsúly. A megfigyelői videográfiától pedig éppen a kérdezés és az aktivitások értelmezésén alapuló - utólagos - interjúszerủ rész miatt különbözik.

A videorögzítésnek itt is kulcsszerepe van, ami élővé, szemléletessé és hitelessé teszi a kutatás végtermékét, az elemző riportot. Ennek ellenére a kamera csak egy eszköz, nem az övé a föszerep. A kvalitatív kutatásban használt etnográfiai interjú nem filmforgatás, sok esetben az a jó, ha a kamera a háttérben marad, és a kutatás alanyai tudomást sem vesznek róla. A végső kutatási jelentésben az általa készített film lényeges - nélküle nem nevezhetnénk etnográfiának az etnográfiát a piackutatásban -, de a leíró elemzés és értelmezés nélkül önmagában nem állja meg a helyét, a kutató értelmezése és a látottak kutatási kontextusba helyezése nélkül kevésbé segíti a kutatási kérdések megválaszolását.

Az akadémikus etnográfia azon fajtáinak, melyek a néprajzhoz kötődnek, szembe kell nézniük azzal a problémával, hogy kérdéseit a modernitás keretei között teszik fel, megfigyelési módszereiket a jelenkorban fejlesztették ki, viszont legtöbb esetben a múlthoz kapcsolódó vagy ott kifejlődött szokásokat, viselkedéseket vizsgálnak (Nagy, 2006). Az akadémikus etnográfiai kutatások széles időperspektívával dolgoznak, hogy megalapozottan tudjanak érvelni, időspektrumukban a múlt is jelentős szerepet kap. A piaci alapon végzett etnográfiai kutatások esetén a modernitás nem jelent hátrányt, hiszen az a jelenkorban kialakult, jelenben érvényes jelenségeket kutatja.

A kvalitatív kutatásban használt etnográfia - az 1. ábra szerint - lefedi az élet legfontosabb dimenzióit, beleértve a fizikai és szociális környezetet, kulturális kontextust és a személyiséget. Ezek a dimenziók folyamatosan hatnak egymásra, együttesen alakítva ki a fogyasztó magatartását, beleértve a vásárlási döntéseit is.

1. ábra

Az etnográfiai kutatás által vizsgált dimenziók

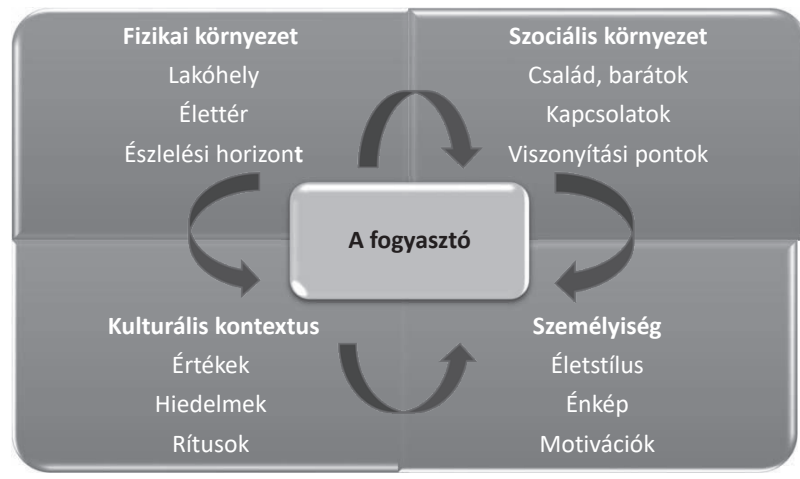

Forrás: saját szerkesztés

Egy megfelelően kivitelezett és értelmezett etnográfiai kutatás után a kutató meg tudja határozni, hogy a célcsoporthoz tartozó kutatási alany hogyan él, milyen emberi 
kapcsolatok befolyásolják a viselkedését, hogyan befolyásolja a környezet az alany viselkedését, mi befolyásolja a döntéseit, van-e különbség az alany által elmondottak és a látottak között, és ha van, mi ennek a különbségnek az oka.

\section{A kvalitatív piackutatásban használt etnográfiai technikák}

A kvalitatív piackutatásban használt etnográfiai technikákat több, mint 20 év piackutatási gyakorlatomból válogattam össze. A kutatások túlnyomó többsége az FMCG-szektorból származik, kiegészítve néhány telekommunikációs szektorban készült etnográfiai kutatás tapasztalataival.

A kvalitatív piackutatásban használt etnográfia egy módszertani tárház, egyfajta „svédasztal”, amiről a kutató a kutatási kérdések megválaszolásához legmegfelelőbb módszertani technikát választja ki. Íme, néhány leggyakrabban használt etnográfiai technika:

- otthoni megfigyelés és interjú,

- shadowing,

- kortárs csoport party,

- elkísért bevásárlás

- shopinsight recording.

Az otthoni megfigyelés és interjú általában az otthoni rutinaktivitásokat követi nyomon, mint a takarítás, mosás, főzés, közös étkezések, médiafogyasztás vagy akár az otthoni sportolás. Ez a módszertan komplex kérdéskörök vizsgálatára is alkalmas. Ilyen például az otthoni étkezések és az ivás kapcsolata. Milyen funkciója van az étkezések mellé fogyasztott italoknak, milyen típusú italok, milyen otthoni étkezésekhez köthetők és az egyes italtípusokhoz milyen értékek kapcsolódnak. Ezzel a módszerrel arra a kérdésre is választ lehet kapni, hogy milyen étkezéstípushoz tud egy üdítőital-márka leghitelesebben csatlakozni, felhasználva a családi étkezések érzelmi töltöttségét.

A shadowing néma követést jelent, általában otthonon kívüli helyszíneken - munkába menet, munkahelyen, szórakozóhelyen - e rutincselekvések interakció nélküli rögzítését jelenti. Akkor hasznos, ha az adott aktivitás alatt az alany vagy az alanyok több otthonon kívüli helyszínt látogatnak meg egymás után. A kutató és a kamerája ilyenkor árnyékként követi őket. A shadowing módszert gyakran használják sör vagy rövidital gyártó cégek, amikor meg akarják ismerni a célcsoportjuk szórakozóhelyi aktivitásait, tipikus viselkedési mintáit és fel akarják tárni az ital és a márkaválasztás mögötti döntési mechanizmusokat.

A kortárs csoport party egy olyan módszer, amely egy korosztályhoz, egy szubkultúrához tartozó vagy egy fizikai környezetben élő, egymással sok időt töltő emberek közös aktivitását figyeli meg, saját környezetükben. Ez a módszertan kiválóan alkalmazható volt egy lakótelepen élő, hasonló korú csecsemőket nevelő anyukák, szoptatási és tápszerhasználati szokásainak feltárására. A módszer teljes mértékben alkalmazkodni tud a meg- figyeltek napi időbeosztásához, mint az etetések időpontjai, délelőtti vagy délutáni séták, vagy a játszótéri aktivitások.

Az elkisért bevásárlás során a kutató lehet passzív szemlélődő és aktív kérdező is, az etnográfiai kutatások során általában a passzív megfigyelés a jellemző. A kutató ilyenkor nem használ technikai eszközöket a rögzítéshez, csak megfigyel, esetleg egy-két lényeges elemet leír - és a látottakról csak a megfigyelt aktivitás végén kérdez. Ez a módszer hasznos lehet akkor, ha például a nők férfi kozmetikum vásárlási szokásait, bolton belüli válogatási és választási mintáit, folyamatát szeretnénk feltárni. Ez a termékkategória azért is izgalmas, mert itt gyakran különválik a vásárló a fogyasztótól, jelen esetben nők vásárolják a terméket a férfiaknak.

A shopinsight recording nem más, mint a vásárlói fókusz rögzítése. A bevásárlás során videoszemüveget visel az interjúalany. Ennek a módszernek a legnagyobb előnye, hogy a kutató személye nem zavarja a vásárlási folyamatot.

A rögzített vásárlást interjúk egészítik ki:

- entry interjú - a vásárlás megkezdése előtt,

- exit interjú - közvetlenül a vásárlás befejezése után,

- checking interjú - az interjúalannyal közösen végignézve és értelmezve a felvett vásárlási folyamatot.

A módszer során objektív és hiteles információkat kapunk a vásárló üzlethasználatáról, figyelméről és döntési folyamatairól, érintve a következő fókuszpontokat:

- vásárlói útvonal rögzítése,

- mennyi időt tölt el egy-egy polc vizsgálatával,

- melyik POS eredményez vásárlást és miért,

- elsődleges, másodlagos kihelyezések szerepe,

- melyik másodlagos kihelyezések a leghatékonyabbak és hol,

- hol nézi az árat, melyik ártábla van hatással a vásárlási döntésre,

- milyen interakció van az eladókkal és az akciók hostesseivel,

- észlelési és viselkedési minták feltárása,

- mi ragadja meg és tartja fenn a figyelmet,

- a figyelem fókuszpontjainak összegyüjtése,

- vásárlói döntést befolyásoló tényezők,

- viselkedésbeli különbségek a tervezett és az impulse vásárlások között.

Ezzel az eszközzel nyomon követhető a vásárló figyelme és az üzleten belüli útvonala. A rögzített film objektív kontrollt biztosít a felidézéshez. A vásárlás után - az otthoni interjú részeként - visszanézhető és elemezhető az interjúalany által rögzített film, ahol az interjúalany saját maga kommentálja, értelmezi a vásárlás folyamatát, mit, miért vett vagy nem vett, milyen szempontokat mérlegelt a döntései során, és a végén miért éppen a választott termék vagy márka mellett döntött. A módszer alkalmas a bolton belüli és kívüli POS-anyagok hatékonyságának előtesztelésére is. 


\section{Az etnográfiai kutatási design, a tartalmi blokkok és a passzív/aktív részek szerepe}

A kutatási design kialakításakor - legtöbb esetben a megrendelővel egyeztetve - meghatározzák, hogy az éppen aktuális kutatási kérdésekre milyen etnográfiai technikát vagy technikákat a leghatékonyabb alkalmazni. Meghatározzuk a kiválasztott technikák sorrendiségét, és azt, hogy melyik technikára, mennyi időt szánunk.

A terepmunka során a rendelkezésre álló időt - ami általában 4-6 óra - tartalmi blokkokra osztjuk, aszerint, hogy milyen tevékenységet akarunk megfigyelni. Lehet, hogy lesz egy vásárlási, hazautazási és otthoni blokkunk, de lehet, hogy az otthoni blokknak is több része van: fözés, takarítás, közös étkezés. Ha például bulizó fiatalok a célcsoport, akkor lehet egy otthoni „,alapozást” nyomon követő kortárs csoport party az első blokk, majd egy szórakozóhelyi aktivitást rögzítő shadowing a második.

A 2. ábra egy összetettebb etnográfiai technikákra épülő konkrét piackutatási projekt forgatókönyvét ábrázolja, ahol a kutatási cél az étkezéshez kapcsolódó üdítőital-fogyasztás volt, különböző korú gyermekekkel rendelkező családok körében.

\section{Az etnográfiai kutatás által vizsgált dimenziók}

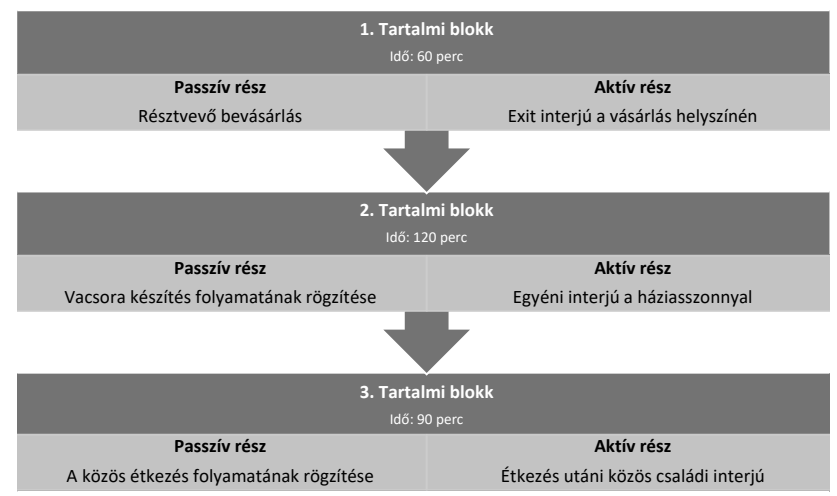

Forrás: saját szerkesztés

Minden tartalmi blokknak két része van, egy passzív és egy aktív rész. Nagyon lényeges a megfigyelésen alapuló passzív rész, és a kérdezéses technikát alkalmazó aktív rész időbeli különválasztása. Bármilyen módszertani technikát is alkalmazunk, a passzív, megfigyelésen alapuló résznek mindig meg kell előznie az aktív, kérdéseket tartalmazó részt. A passzív részben a kutató nem lép interakcióba a megfigyeltekkel, csak a kamera rögzíti az eseményeket.

A passzív részben a kutatónak a lehető legjobban a háttérben kell maradnia, minimális interakcióra kell törekednie a megfigyeltekkel, egyfajta ,élő kameraállvánnyá” kell válnia. Fontos, hogy ebben a részben ne csak a megfigyeltek aktivitását rögzítsük, hanem a környezetet is. A környezeti elemek rögzítése - milyen márkák vannak a polcokon, milyen újságok vannak a nappaliban, mi megy éppen a TV-ben - később nagy segítségére lehet a kutatónak a látott aktivitások és az elmondott értelmezések elemzésében.

Az etnográfiai kutatás mindig csapatmunka. Ennek elle- nére azonban nagyon zavaró, ha a terepen kettőnél több kutató van jelen. Legjobb, ha a kutató egyedül látogat el egy családhoz, az aktív és a passzív részek időbeli különválása miatt nem okoz nehézséget a kamera vagy a diktafon kezelése és a kérdezés. Ha csoportokat figyelünk meg, akkor hatékonyabb, ha két kutató van jelen a terepen, hiszen akkor a megfigyelni való is több, a gazdagabb információ több szempontú megfigyelést igényel.

Lényeges kérdés a megrendelő jelenléte a terepen. Sok megbízó azért is választja az etnográfia módszerét, mert saját szemével akarja látni a valós fogyasztót, valós fogyasztási vagy élethelyzetben. A legtöbb esetben érdemes korlátozni az egy helyszínen a kutatókhoz csatlakozó ügyfelek számát egy személyben. Családok megfigyelésekor 1 kutató +1 ügyfél az ideális létszám, csoportok megfigyelése esetén 2 kutató 1 vagy maximum 2 ügyfél. Minél több az idegen a megfigyelni kívánt helyszínen - legyen az kutató vagy ügyfél - annál nehezebb elvárni a természetes viselkedést a megfigyeltektől.

\section{Az etnográfiai kutatások jövője - online technológiák az offline viselkedések megfigyelésében és rögzítésében}

Az információs technológia fejlődésének köszönhetően a mindennapi élet pillanatainak rögzítése és megosztása teljesen elfogadottá és hétköznapivá vált. Az okostelefonok elterjedése óta a telefonnal készített fotók és videofelvételek megszokottak, mindennapiak, ezért kevésbé zavaróak. Egy telefon a kutató kezében sokkal kevésbé idegen, mint egy kézi kamera, legyen az bármilyen kicsi méretü. Az aktivitásokat a telefon kamerájával rögzítő kutató szinte teljesen beleolvad a környezetbe, az alanyok észre sem veszik, hogy „filmezik őket”, kevesebb a szorongás, a lámpaláz, a „,bemelegedésre” szánt idők lerövidülnek. Természetesen csak a megfelelő minőségü telefonokkal készített felvételek az elfogadhatók, ahol minimálisan a full HD felbontás (1080x1920 pixel) garantált. A házon belüli, nem természetes fény mellett készült felvételeknél - a telefon optikájának korlátai miatt - még ezek a magas minőségü felvételek sem érik el egy jó minőségű kézi kamera színvonalát. Ennek ellenére az okostelefon használatának mindennapisága az etnográfiai kutatás során könnyebb elfogadást és természetesebb viselkedést eredményez.

Mind az akadémiai, mind a kvalitatív piackutatásban használt etnográfiai kutatásokban egyre nagyobb szerepet játszanak azok a digitális technológiák, melyek intenzíven jelen vannak a kutatás résztvevőinek mindennapi életében. Érdemes ezeket a lehetőségeket video- vagy fotónapló készítésére felhasználni. Az interjúalanyoknak lehetőségük van a saját maguk által készített videoanyagokat egy adott tárhelyre - egy alkalmazás segítségével - feltölteni, kommentálni, rendszerezni. Jóllehet ez az, „önmegfigyelés” nem helyettesíti a kutató jelenlétét a terepen, de sokat segít az utólagos elemzésben, a prioritások felállításában vagy a kutató figyelmét esetleg elkerülő tényezők azonosításában.

Az etnográfia az egyik legköltségesebb és leginkább idöigényes kvalitatív kutatási módszertan. A mobil- és az online technológiák azonban nagymértékben lecsökkenthetik a kutatás költségeit és időigényét. Az interjúalanyok által készített digitális naplók pedig a kutatás hitelességét és tudományos 
értékét növelhetik, mivel csökkentik a kutató sokat kritizált szubjektivitását a megfigyelés és az elemzés során.

\section{Összegzés}

Az akadémiai és a kvalitatív piackutatásban használt etnográfiai kutatások közötti legfőbb különbségeket az 1. táblázat foglalja össze.

\section{Az akadémiai és a kvalitatív piackutatásban használt etnográfiai kutatások közötti különbségek}

\begin{tabular}{|c|c|c|}
\hline & $\begin{array}{l}\text { Etnográfia az } \\
\text { akadémiai kuta- } \\
\text { tásokban }\end{array}$ & $\begin{array}{l}\text { Etnográfia a piac- } \\
\text { kutatásban }\end{array}$ \\
\hline Cél & $\begin{array}{l}\text { - választ keresni } \\
\text { néprajzi, szocio- } \\
\text { lógiai, társada- } \\
\text { lomtudományi, } \\
\text { pszichológiai } \\
\text { vagy fogyasztói } \\
\text { magatartást érin- } \\
\text { tő kérdésekre }\end{array}$ & $\begin{array}{l}\text { - marketingtanács- } \\
\text { adási folyamat } \\
\text { részeként választ } \\
\text { adni az adott üzle- } \\
\text { ti kutatási kérdé- } \\
\text { sekre }\end{array}$ \\
\hline $\begin{array}{l}\text { Értelmezési } \\
\text { spektrum }\end{array}$ & $\begin{array}{l}\text { - széles megfigye- } \\
\text { lési és értelmezé- } \\
\text { si spektrum }\end{array}$ & $\begin{array}{l}\text { - projektalapú - } \\
\text { - adott kutatási } \\
\text { kérdésre fókuszált } \\
\text { spektrum }\end{array}$ \\
\hline Időtáv & - szélesebb időtáv & $\begin{array}{c}\text { rövidebb, hatá- } \\
\text { ridőhöz kötött }\end{array}$ \\
\hline $\begin{array}{l}\text { Személyes tapasz- } \\
\text { talat szerepe }\end{array}$ & $\begin{array}{l}\text { - lényeges lehet a } \\
\text { kutató személyes } \\
\text { tapasztalata }\end{array}$ & $\begin{array}{l}\text { - a kutató kizárja } \\
\text { személyes tapasz- } \\
\text { talatait }\end{array}$ \\
\hline Időfókusz & $\begin{array}{l}\text { - múltra és a jelen- } \\
\text { re fókuszál }\end{array}$ & $\begin{array}{l}\text { - elsősorban a jelen- } \\
\text { re fókuszál } \\
\end{array}$ \\
\hline $\begin{array}{l}\text { A résztvevők szü- } \\
\text { rése }\end{array}$ & $\begin{array}{l}\text { - széles merítés } \\
\text { vagy nincs szürés }\end{array}$ & \begin{tabular}{|c|} 
- kvótaspecifikus \\
szürés jellemzö
\end{tabular} \\
\hline $\begin{array}{l}\text { A megfigyelés } \\
\text { típusai }\end{array}$ & $\begin{array}{l}\text { - résztvevő- és } \\
\text { nem-résztvevő } \\
\text { megfigyelés egy- } \\
\text { aránt jellemző }\end{array}$ & $\begin{array}{l}\text { - nem-résztvevő } \\
\text { megfigyelés a } \\
\text { jellemző }\end{array}$ \\
\hline
\end{tabular}

Forrás: saját szerkesztés

Az akadémiai és a piackutatásban használt etnográfiai kutatásoknak több közös pontjuk is van, de jól körülhatárolható különbségekkel is rendelkeznek. Az akadémiai etnográfiai kutatásoknak sokszor nincs egy meghatározott, leszükített kutatási céljuk, megfigyelési és értelmezési spektrumuk széles. Ezzel szemben a piackutatásban végzett etnográfiai kutatások mindig valamilyen profitorientált célt szolgálnak, egy-egy elöre meghatározott kérdéskörre keresik a választ. Más a kutatások időíve: az akadémiai etnográfiai kutatások sokszor éveken keresztül tartanak, a piackutatási projektek pedig egy-két hónapig. A kutatási eredmények gyakorlati alkalmazhatósága az akadémiai kutatásokban csak az egyik dimenzió, a piacorientált kutatások esetén viszont ez a legfontosabb szempont. Különbség még a kutató korábbi tapasztalata, ami az akadémiai etnográfiai kutatások esetében lényeges elem, míg a piackutatásban a kutató igyekszik kizárni a saját és a korábbi tapasztalatait.

Az akadémiai etnográfiai kutatásokra nem jellemző, a piackutatásban viszont szinte mindig használt előszelekciós technika a kvótaspecifikus szürés. Az akadémikus etnográfiai kutatásokra széles időperspektíva a jellemző, a piaci alapon végzett etnográfiai kutatások esetén a fókusz leginkább a jelen történéseinek, cselekvéseinek a megfigyelésén van.

A technikai eszközök fejlödése, a mobiltelefonok kameraként való használata - akár a kutató, akár a megfigyeltek részéről - újabb lehetőségeket nyit mind az akadémiai, mind a piackutatásban használt etnográfiai kutatásokban. A kvalitatív piackutatásban egyre inkább elvárás, hogy a kutatási eredmények ne csupán a megkérdezettek utólagos felidézésén alapuljanak, hanem valós történéseken. A kutatás során elötérbe kerül a fogyasztói attitüd viselkedési komponensének vizsgálata, ami a jövőben felerősítheti az etnográfiai módszerek szerepét a piacorientált kvalitatív kutatásokban.

\section{Felhasznált Irodalom}

Arnould, E. J. - Wallendorf, M. (1994): Market-oriented ethnography: interpretation building and marketing strategy formulation. Journal of Marketing, Vol. 31, No. 4, p. 484-504.

Belk, R. W. - Kozinets, R. V. (2005): Videography in marketing and consumer research. Qualitative Market Research, Vol. 8, No. 2, p. 128-141.

Dörnyei Krisztina - Mitev Ariel (2010): Netnográfia, avagy on-line karosszék-etnográfia a marketingkutatásban. Vezetéstudomány, XII. évf. 2010. 4. szám

Dörnyei Krisztina - Mitev Ariel (2011): A mozgókép reneszánsza: nagytotál a videográfia módszertanáról. (Mok, 2011)

Jorgensen, D. L. (1989): Participant Observation: A Methodology for Human Studies, Vol. 15, Applied Research Methods Series. Newbury Park, CA: Sage Publications

Joy, A. (1991): Beyond the Odyssey: Interpretations of Ethnographic Writing in Consumer Behaviour. In: Highways and Buyways: Naturalistic Research from the Consumer Behaviour Odyssey. Provo, UT: Association for Consumer Research, p. 216-233.

Kozinets, R. V. (2002): The Field Behind the Screen: Using Netnography For Marketing Research in Online Communities. Journal of Marketing Research, 39 (February), p. 61-72.

Lerum, K. (2001): Subjects of Desire: Academic Armor. Intimate Ethnography, and the Production of Critical Knowledge. Qualitative Inquiry, August 2001 vol. 7, Seattle University

Letenyei László (2012): Kulturális antropológia. Budapest: Typotex Kiadó

Mitev Ariel Zoltán (2012): Grounded theory, a kvalitatív kutatás klasszikus mérföldköve. Vezetéstudomány, XIII. évf. 2012. 1. szám

Nagy K. Zs. (2006): Interaktív etnográfia. Homrogd vizuális atlasza. Tabula, 2 .

Pink, S. (2007): Doing Visual Ethnography. London: Sage

Vörös M. - Frida B. (2004): Az antropológiai résztvevő-megfigyelés története. In: Letenyei László (szerk.): Településkutatás. Szöveggyüjtemény. Budapest: L’Harmattan - Ráció Kiadó, p. 395-416. 